\title{
Dry Reforming of Methane Over Various Doping Level of Ce on $\mathrm{La}_{1-x} \mathrm{Ce}_{x} \mathrm{Ni}_{0.4} \mathrm{Fe}_{0.6} \mathrm{O}_{3}$ Perovskite Nanocatalyst
}

\section{PARASTOO DEZVAREH ${ }^{1}$, MOAYED HOSSAINI SADR ${ }^{2 *}$, HAMIDREZA AGHABOZORG ${ }^{3}$ and KARIM ZARE ${ }^{4}$}

\author{
'Department of Chemistry, Science and Research Branch, Islamic Azad University, Tehran, Iran. \\ 2Department of Chemistry, Tarbiat Moallem University of Azarbaijan, Tabriz, Iran. \\ ${ }^{3}$ Research Institute of Petroleum Industry, Tehran, Iran. \\ ${ }^{4}$ Department of Pure Chemistry, Shahid Beheshti University, Tehran, Iran. \\ *Corresponding author E-mail address: sadr@azaruniv.edu
}

http://dx.doi.org/10.13005/ojc/320526

(Received: June 13, 2016; Accepted: September 21, 2016)

\begin{abstract}
The $\mathrm{La}_{1-\mathrm{x}} \mathrm{Ce}_{x} \mathrm{Ni}_{0.4} \mathrm{Fe}_{0.6} \mathrm{O}_{3}(x=0.1,0.2$ and 0.3$)$ perovskite nanostructures were prepared via citrate sol-gel method. Synthesized samples were characterized by $X$-ray diffraction (XRD), temperature programmed reduction (TPR), and inductively coupled plasma (ICP) techniques. Specific surface area was determined by BET measurement. Scanning and transmission electron microscopy techniques were applied to study the morphology of the prepared samples. XRD patterns confirmed that a well-crystallized perovskite structure was formed in doping level up to $x=0.2$. Morphology results showed that homogenous particles in the range of nanometers were obtained through the applied synthesis method. TPR analysis revealed that by increasing the doping level of Ce up to 0.2 in the prepared samples, reduction process shifted to lower temperatures. The addition of $\mathrm{Ce}$ to $\mathrm{La}_{1-x} \mathrm{Ce}_{x} \mathrm{Ni}_{0.4} \mathrm{Fe}_{0.6} \mathrm{O}_{3}$ enhances the catalytic activity up to $x=0.2$, but decreased significantly when $x>0.2$. Catalytic activity of $\mathrm{La}_{1-x} \mathrm{Ce}_{x} \mathrm{Ni}_{0.4} \mathrm{Fe}_{0.6} \mathrm{O}_{3}$ perovskites in dry reforming of methane (DRM) were: $\mathrm{LaNiO}_{3}>\mathrm{La}_{0.8} \mathrm{Ce}_{0.2} \mathrm{Ni}_{0.4} \mathrm{Fe}_{0.6} \mathrm{O}_{3}>\mathrm{La}_{0.9} \mathrm{Ce}_{0.1} \mathrm{Ni}_{0.4} \mathrm{Fe}_{0.6} \mathrm{O}_{3}>\mathrm{LaNi}_{0.4} \mathrm{Fe}_{0.6} \mathrm{O}_{3}>\mathrm{La}_{0.7} \mathrm{Ce}_{0.3} \mathrm{Ni}_{0.4} \mathrm{Fe}_{0.6} \mathrm{O}_{3}$
\end{abstract}

Keywords: Ce-substitution, perovskite, nanocatalyst,

Citrate sol-gel method, dry reforming of methane (DRM).

\section{INTRODUCTION}

Dry reforming of methane (DRM)

$$
\begin{array}{cc}
\mathrm{CH}_{4}+\mathrm{CO}_{2} \leftrightarrow 2 \mathrm{CO}+2 \mathrm{H}_{2} & \Delta \mathrm{H}_{298 \mathrm{k}}=247 \mathrm{~kJ} / \mathrm{mol} \\
\mathrm{CO}_{2}+\mathrm{H}_{2} \leftrightarrow \mathrm{H}_{2} \mathrm{O}+\mathrm{CO} & \Delta \mathrm{H}_{298 \mathrm{k}}=41 \mathrm{~kJ} / \mathrm{mol}
\end{array}
$$

has attracted academic and industrial researches to produce synthesis gas (syn-gas: $\mathrm{H}_{2}+\mathrm{CO}$ ). This process converts two of the greenhouse gases including $\mathrm{CH}_{4}$ and $\mathrm{CO}_{2}$ to obtain syn-gas with an appropriate $\mathrm{H}_{2} / \mathrm{CO}$ ratio for several applications. It also reduces $\mathrm{CO}_{2}$ and $\mathrm{CH}_{4}$ emissions contributing to the greenhouse effect ${ }^{1-2}$. Synthesis gas can be 
applied in the Fischer-Tropsch synthesis industry to produce valuable chemicals ${ }^{3,4}$. The low $\mathrm{H}_{2} / \mathrm{CO}$ ratio is preferentially used for further applications such as methanol and liquid fuel synthesis ${ }^{5,6}$. In recent years complex mixed metal oxides with the perovskite-type structure have been studied in catalysis and have been proposed for methane-reforming reactions in replacement of classical catalysts such as noble metal-based catalysts ${ }^{7,8}$. Considerable researches have been focused on the activity and stability of perovskite-type oxides applied in this process ${ }^{9,10}$. Perovskite-type oxides with general formula $\mathrm{ABO}_{3}$ (A: lanthanides, alkali metals, and alkali earth metals; $\mathrm{B}$ : transition elements) show promising performance as catalysts in dry reforming of methane. $A$ is a large cation responsible for the thermal resistance and $B$ is a redox cation responsible for catalytic activity ${ }^{11}$. Perovskite-type oxides have many advantages such as high metallic dispersion, coke formation resistance and nanometer scale particles ${ }^{12}$. Possibility of total or partial substitution A- and/or B-sites cations leads to modifying their oxidation state, oxygen mobility in crystal lattice and the redox properties ${ }^{13}$, ${ }^{14}$. Some examples of $\mathrm{La}$ substitution in $\mathrm{La}_{1-x} \mathrm{M}_{x} \mathrm{NiO}_{3}$ structure that leads to promoting catalytic activity are $\mathrm{M}=\mathrm{Ce}^{15,16,17}$ and $\mathrm{Sr}^{18}$. The resulting compounds show high resistance to carbon deposition because of the existence of $\mathrm{Ni}$ crystallite size and a large number of oxygen vacancies. Ce- substituted catalysts promote catalytic performance because of their high oxygen storage capacity and high lattice oxygen mobility ${ }^{16}$. Sutthiumporn et al. reported that substitution at B-site significantly improves structural stability and catalytic behavior ${ }^{18}$. Jahangiri et al. reported the performance of perovskite-type oxides $\mathrm{La}_{1-x} \mathrm{Sm}_{x} \mathrm{NiO}_{3}, \mathrm{LaNi}_{1-x} \mathrm{Fe}_{x} \mathrm{O}_{3}$ and $\mathrm{LaNi}_{1-x} \mathrm{Co}_{x} \mathrm{O}_{3}$ as catalyst precursors in combined reforming of methane (CRM) with $\mathrm{CO}_{2}$ and $\mathrm{O}_{2}$ by changing doping level $(x)^{19,21}$. The properties of the perovskites greatly depends on the choice of $A$ and $B$ cations so we decided to study the effect of these changes. In the present research $\mathrm{La}_{1-x} \mathrm{Ce}_{x} \mathrm{Ni}_{0.4} \mathrm{Fe}_{0.6} \mathrm{O}_{3}$ perovskites with different doping level up to $x=0.3$ were synthesized. The catalytic activity of the synthesized samples is investigated in dry reforming of methane.

\section{EXPERIMENTAL}

\section{Preparation of catalysts}

$\mathrm{La}_{1-x} \mathrm{Ce}_{x} \mathrm{Ni}_{0.4} \mathrm{Fe}_{0.6} \mathrm{O}_{3}$ samples have been prepared according to the citrate sol-gel method. Stoichiometric amount of the cation at $\mathrm{A}$ site were used. $\mathrm{La}\left(\mathrm{NO}_{3}\right)_{3} \cdot 6 \mathrm{H}_{2} \mathrm{O}($ Merck, $>99 / 9 \%)$, $\mathrm{Ce}\left(\mathrm{NO}_{3}\right)_{3} \cdot 6 \mathrm{H}_{2} \mathrm{O}$ (Merck, $\left.>99 \%\right), \mathrm{Ni}\left(\mathrm{NO}_{3}\right)_{2} \cdot 6 \mathrm{H}_{2} \mathrm{O}$ (Merck, $>99 \%), \mathrm{Fe}\left(\mathrm{NO}_{3}\right)_{2} \cdot 6 \mathrm{H}_{2} \mathrm{O}$ (Merck, $\left.>99 \%\right)$, citric acid (Merck, $99 / 5 \%$ ), and ethylene glycol (99\%) were

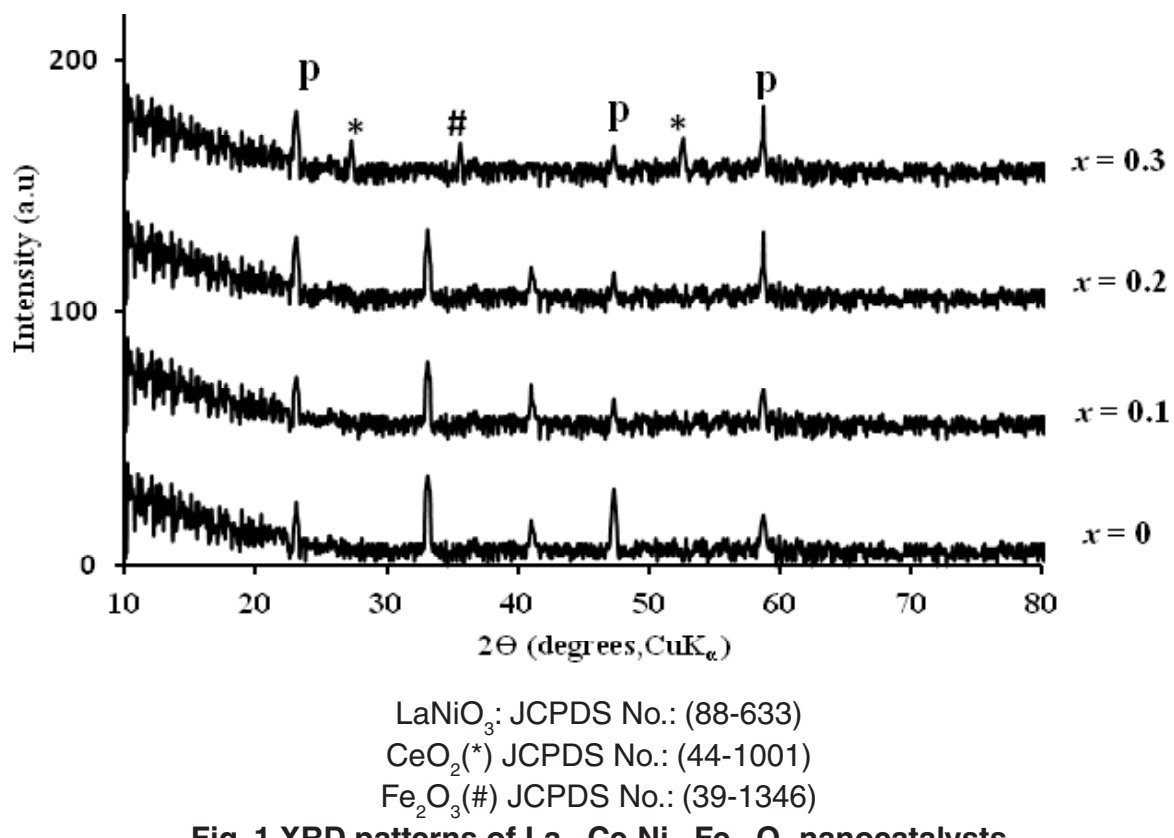

Fig. 1 XRD patterns of $\mathrm{La}_{1-x} \mathrm{Ce}_{x} \mathrm{Ni}_{0.4} \mathrm{Fe}_{0.6} \mathrm{O}_{3}$ nanocatalysts 
applied in this method. Appropriate stoichiometric amount of lanthanum, cerium, nickel and iron nitrates solution $(1 \mathrm{M})$ were mixed and stirred for 40 minutes in $80^{\circ} \mathrm{C}$, and then citric acid and ethylene glycol were added to this solution with molar ratio of 1 . The sol formation started and then the excess water was slowly removed within $8 \mathrm{~h}$ at $80^{\circ} \mathrm{C}$ until transformation of sol into spongy gel occured and an amorphous gel was formed. The gel was finally dried at $110^{\circ} \mathrm{C}$ for $24 \mathrm{~h}$ and calcined in air at $800^{\circ} \mathrm{C}$ within $2 \mathrm{~h}$. The heating rate was $1^{\circ} \mathrm{C} / \mathrm{min}$. up to $350^{\circ} \mathrm{C}$ and $3^{\circ} \mathrm{C} / \mathrm{min}$. up to $800^{\circ} \mathrm{C}$.

\section{Characterization techniques}

The specific surface areas of the samples were measured using $\mathrm{N}_{2}$ at $77 \mathrm{~K}$ on a Tristar 3000 , Micrometrics apparatus by applying the multipoint BET method. Powder X-ray diffraction were obtained on a Phillips PW 1840 diffractometer equipment with a copper anode (CuK $\alpha$ monochromatized radiation source, $\lambda=1.54056 \AA$ ) to confirm the formation of the perovskite structure, phase purity and particle size determination. XRD profiles were collected in the $2 \theta$ range, $10-80^{\circ}$, in steps of $5 \% \mathrm{~min}$. The catalyst phases were identified by comparing the observed results with the JCPDS database. The morphologies and determination of chemical compositions of the calcined catalysts were determined by scanning electron microscopy (SEM) images using a Philips XL30 microscope. Temperature-programmed reduction (TPR) was performed with a semiautomatic micrometrics TPD/ TPR 29000 apparatus to investigate the reduction properties of the catalysts. Inductively coupled plasma (ICP) emission spectroscopy (Perkin-Elmer ICP/5500) was used to determine the metals.

\section{Measuring catalytic activity}

Catalytic activity in dry reforming of methane was evaluated as a function of the composition of the precursors and temperature of the reaction. The experimental tests of the catalyst activity were carried out using the feed gases $\left(\mathrm{CH}_{4}, \mathrm{CO}_{2}, \mathrm{~N}_{2}\right.$ and $\mathrm{H}_{2}$ ) with ultra-high pure grade (>99.999\%) in microreactor by mass flow controllers (Model 5850, Brooks Instrument). The temperature of micro-reactor was measured and controlled with two thermocouples (Ni-Cr, K-Type, $0.5 \mathrm{~mm}$ diameter) and two PID thermo-controllers (Model Jumo iTRON08). The catalyst ( $0.4 \mathrm{~g}$ for all cases) was loaded in the middle of the reactor, and the feed gases at a total flow rate of $100 \mathrm{ml} / \mathrm{min}$ (WHSV=15 l/(h.g), $\mathrm{CH}_{4} / \mathrm{CO}_{2} /=1 / 1$ ) under atmospheric pressure were introduced into the reactor as the default. Catalytic activity was studied under a temperature treatment between $600^{\circ} \mathrm{C}$ and $800^{\circ} \mathrm{C}$. The reactants and products were analyzed by a gas chromatograph (Model 6890N, Agilent Technologies) provided with two detectors (FID and TCD). Prior to activity measurements, catalyst precursors were reduced in situ in a flow of $20 \% \mathrm{H}_{2} / \mathrm{N}_{2}$ mixture (total flow rate of $50 \mathrm{ml} / \mathrm{min}$ ) at $700^{\circ} \mathrm{C}$ for $2 \mathrm{~h}$ to generate the metal phase. In all tests, the performances were evaluated by conversions. The $\mathrm{CH}_{4}$ and $\mathrm{CO}_{2}$ conversions, $\mathrm{H}_{2}$ and $\mathrm{CO}$ yields and $\mathrm{H}_{2} / \mathrm{CO}$ ratios are defined as follows ${ }^{22}$ :

$$
\begin{aligned}
& \mathrm{CH}_{4} \text { Conversion }(\%)=\frac{\mathrm{CH}_{4, \text { in }}-\mathrm{CH}_{4, \text { out }}}{\mathrm{CH}_{4, \text { in }}} \times 100 \\
& \mathrm{CO}_{2} \text { Conversion }(\%)=\frac{\mathrm{CO}_{2, \text { in }}-\mathrm{CO}_{2, \text { out }}}{\mathrm{CO}_{2, \text { in }}} \times 100 \\
& \text { Yield of } \mathrm{H}_{2}(\%)=\frac{\mathrm{H}_{2, \text { out }}}{2 \mathrm{CH}_{4, \text { in }}} \times 100
\end{aligned}
$$

Table 1: Elemental analysis by ICP (nominal values in parenthesis),

\begin{tabular}{|c|c|c|c|c|c|c|}
\hline$x$ & La(wt.\%) $)^{\star}$ & $\mathrm{Ce}(w t \%)$ & $\begin{array}{c}\mathrm{La}_{1-x} \mathrm{Ce}_{x} \mathrm{Ni}_{0.4} \mathrm{Fe}_{0.6} \mathrm{O}_{3} \\
\mathrm{Ni}(w \mathrm{wt} \%)\end{array}$ & $\mathrm{Fe}(w t \%)$ & $\mathrm{SA}\left(\mathrm{m}^{2} / \mathrm{g}\right)$ & $D(\mathrm{~nm})$ \\
\hline 0 & $69.8(70.9)$ & $00.0(00.0)$ & $12.2(12.0)$ & $18.0(17.1)$ & 5.4 & 49 \\
\hline 0.1 & $64.1(63.7)$ & $6.5(7.0)$ & $12.3(12.0)$ & 17.1(17.3) & 13.4 & 43 \\
\hline 0.2 & $55.4(56.6)$ & $15.0(14.3)$ & $11.6(12.0)$ & $18.0(17.1)$ & 21.7 & 38 \\
\hline
\end{tabular}
BET surface areas, and crystallite size of some $\mathrm{La}_{1-x} \mathrm{Ce}_{x} \mathrm{Ni}_{0.4} \mathrm{Fe}_{0.6} \mathrm{O}_{3}$ perovskites (calculated by Scherrer equation)

nominal values in parentheses ${ }^{\star} S A=B E T$ surface area $D=$ crystallite size 
Yield of $\mathrm{CO}(\%)=\frac{\mathrm{CO}_{\text {out }}}{\mathrm{CH}_{4, \text { in }}} \times 100$

$\frac{\mathrm{H}_{2}}{\mathrm{CO}}$ ratio $=\frac{\text { moles of } \mathrm{H}_{2} \text { produced }}{\text { moles of } \mathrm{CO} \text { in feed }}$

\section{RESULTS AND DISCUSSIONS}

Characterization of the $\mathrm{La}_{1-x} \mathrm{Ce}_{x} \mathrm{Ni}_{0.4} \mathrm{Fe}_{0.6} \mathrm{O}_{3}$ samples

Crystalline structure

The XRD patterns of the $\mathrm{La}_{1-x} \mathrm{Ce}_{x} \mathrm{Ni}_{0.4} \mathrm{Fe}_{0.6} \mathrm{O}_{3}$ samples for $x=0.0$ up to 0.3 are displayed in Fig.1. For $\mathrm{La}_{1-x} \mathrm{Ce}_{x} \mathrm{Ni}_{0.4} \mathrm{Fe}_{0.6} \mathrm{O}_{3}$ samples $(x=0.0$, $0.1,0.2)$, diffraction lines are characteristic of the $\mathrm{LaNiO}_{3}$ perovskite phase (JCPDS No.: 88-633) at the absence of any other crystalline phases. For substitution degree of $x=0.3$ detailed examination of this pattern also revealed not only diffraction lines of the perovskite, but also lines indicating that $\mathrm{Ce}$ and $\mathrm{Fe}$ existed separately in the forms of $\mathrm{CeO}_{2}$ and $\mathrm{Fe}_{2} \mathrm{O}_{3}$. Lines representing $\mathrm{NiO}$ were not observed in this study, probably in the form of an amorphous phase $^{23}$.

\section{Chemical analysis and surface area measurement}

The chemical composition (wt.\%) and surface area for some prepared samples are reported in Table 1. The ICP values reveal that the experimental data for $\mathrm{La}, \mathrm{Ce}, \mathrm{Ni}, \mathrm{Fe}$ (wt.\%) are close to the nominal value (reported in parenthesis). These results confirm the effectiveness of preparation procedure. BET surface areas of the catalysts are in the range of $5-22 \mathrm{~m}^{2} \mathrm{~g}^{-1}$. Long exposure to high temperatures has led to low surface area solids. The crystallite size of the prepared samples was calculated by Scherrer equation using the most intense peak, presented in Table 1. The results showed that the particle size of the prepared samples was in nanoscale.in parentheses
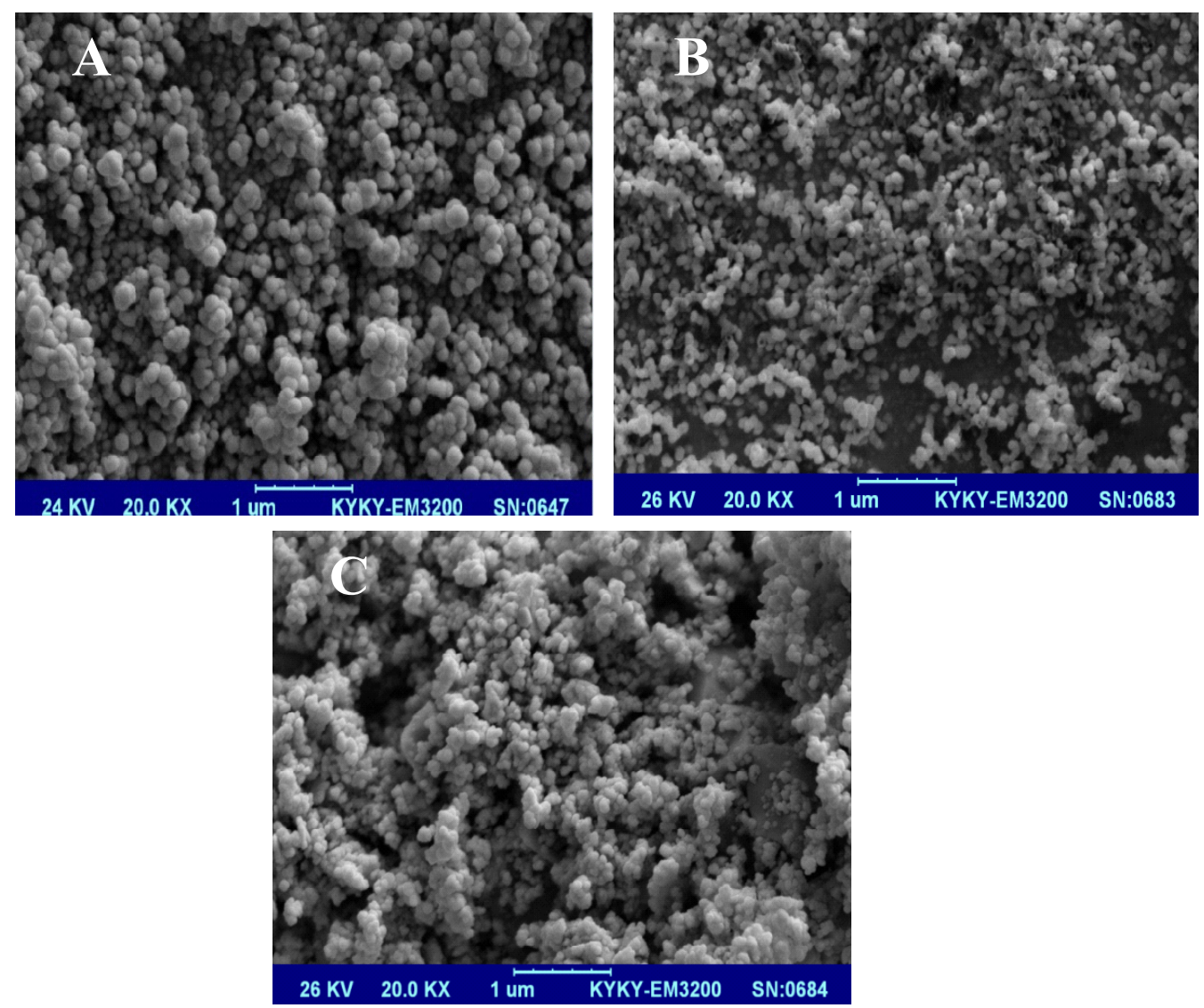

Fig. 2: SEM images of $\mathrm{La}_{1-x} \mathrm{Ce}_{x} \mathrm{Ni}_{0.4} \mathrm{Fe}_{0.6} \mathrm{O}_{3}((x=0.1)(\mathrm{A}),(x=0.2)(\mathrm{B}),(x=0.3)(\mathrm{C}))$ 


\section{Morphology}

The morphology of the perovskites was studied by SEM and TEM. The SEM and TEM images are shown in Figs. 2 and 3, respectively. The SEM and TEM images show a uniform nanostructured texture with spherical particles, agglomerated and fine with a variable size of $40-50 \mathrm{~nm}$.

\section{Reducibility study of $\mathrm{La}_{1-x} \mathrm{Ce}_{x} \mathrm{Ni}_{0.4} \mathrm{Fe}_{0.6} \mathrm{O}_{3}$}

Since active sites for the reforming reaction are metalic nickel species, the catalysts must be reduced prior to application in the reaction tests. Fig. 4 indicates the results of TPR experiments. In the case of $x=0$, the reduction of $\mathrm{Ni}^{3+}$ and $\mathrm{Ni}^{2+}$

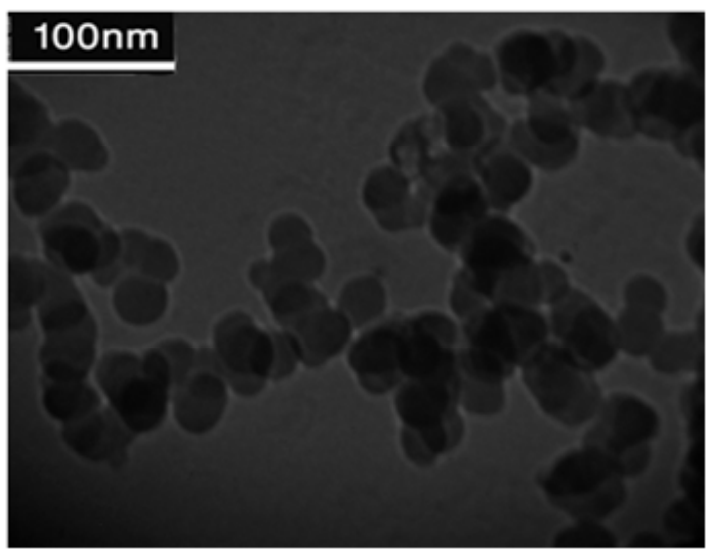

Fig. 3: TEM image of $\mathrm{La}_{1-x} \mathrm{Ce}_{x} \mathrm{Ni}_{0.4} \mathrm{Fe}_{0.6} \mathrm{O}_{3}$ perovskite $(x=0.2)$

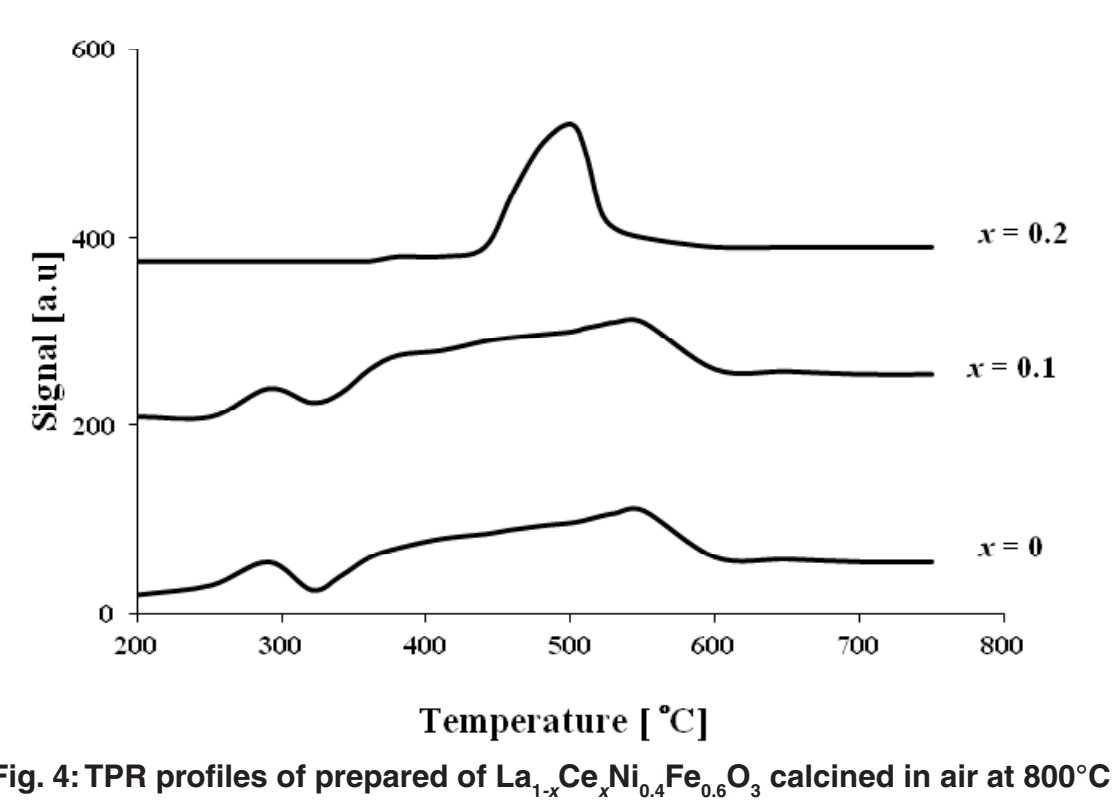

Temperature $\left[{ }^{\circ} \mathrm{C}\right.$ ]

Fig. 4: TPR profiles of prepared of $\mathrm{La}_{1-x} \mathrm{Ce}_{x} \mathrm{Ni}_{0.4} \mathrm{Fe}_{0.6} \mathrm{O}_{3}$ calcined in air at $800^{\circ} \mathrm{C}$ ions represent weak and broad peaks ${ }^{23,24}$, in the range of 300 and $550^{\circ} \mathrm{C}$, indicating that the $\mathrm{Ni}$ ions in the perovskite structure were not easily reduced. A similar result was observed when $C e$ was added $x=0.1$. When the amount of added Ce increased to $x=0.2$, the broad peaks were replaced with an intense peak, centered at $500^{\circ} \mathrm{C}$. This result shows that $\mathrm{Ni}$ ions were more easily reduced when $x=0.2$.

\section{Catalytic activity}

Catalytic performance of the prepared samples in the temperature range of $600-800^{\circ} \mathrm{C}$ has been studied in DRM process. The $\mathrm{CH}_{4} \& \mathrm{CO}_{2}$ conversions and $\mathrm{H}_{2}$ \& $\mathrm{CO}$ yields in the presence of $\mathrm{La}_{1-x} \mathrm{Ce}_{x} \mathrm{Ni}_{0.4} \mathrm{Fe}_{0.6} \mathrm{O}_{3}$ in different temperatures are presented in Fig. 5. As it is shown, $\mathrm{CH}_{4}$ and $\mathrm{CO}_{2}$ conversions increase by increasing the temperature and the $\mathrm{CO}_{2}$ conversions are always higher than that of $\mathrm{CH}_{4}$. This behavior can be due to consuming of $\mathrm{CO}_{2}$ in reaction equations 1 and 2. In addition, both $\mathrm{H}_{2}$ and $\mathrm{CO}$ yields increase by rising reaction temperature and the $\mathrm{CO}$ yields are higher than that of $\mathrm{H}_{2}$ in the presence of the $\mathrm{La}_{1}$. ${ }_{x} \mathrm{Ce}_{x} \mathrm{Ni}_{0.4} \mathrm{Fe}_{0.6} \mathrm{O}_{3}$ catalysts. This behavior is more significant at higher temperatures. In the presence of $\mathrm{La}_{1-x} \mathrm{Ce}_{x} \mathrm{Ni}_{0.4} \mathrm{Fe}_{0.6} \mathrm{O}_{3}$ samples with partial doping level of $x=0.3$, there is no significant $\mathrm{CH}_{4}$ and $\mathrm{CO}_{2}$ conversions and product yields for each temperature. Fig. 6 indicates the $\mathrm{CH}_{4}$ \& $\mathrm{CO}_{2}$ conversions, and $\mathrm{H}_{2}$ 

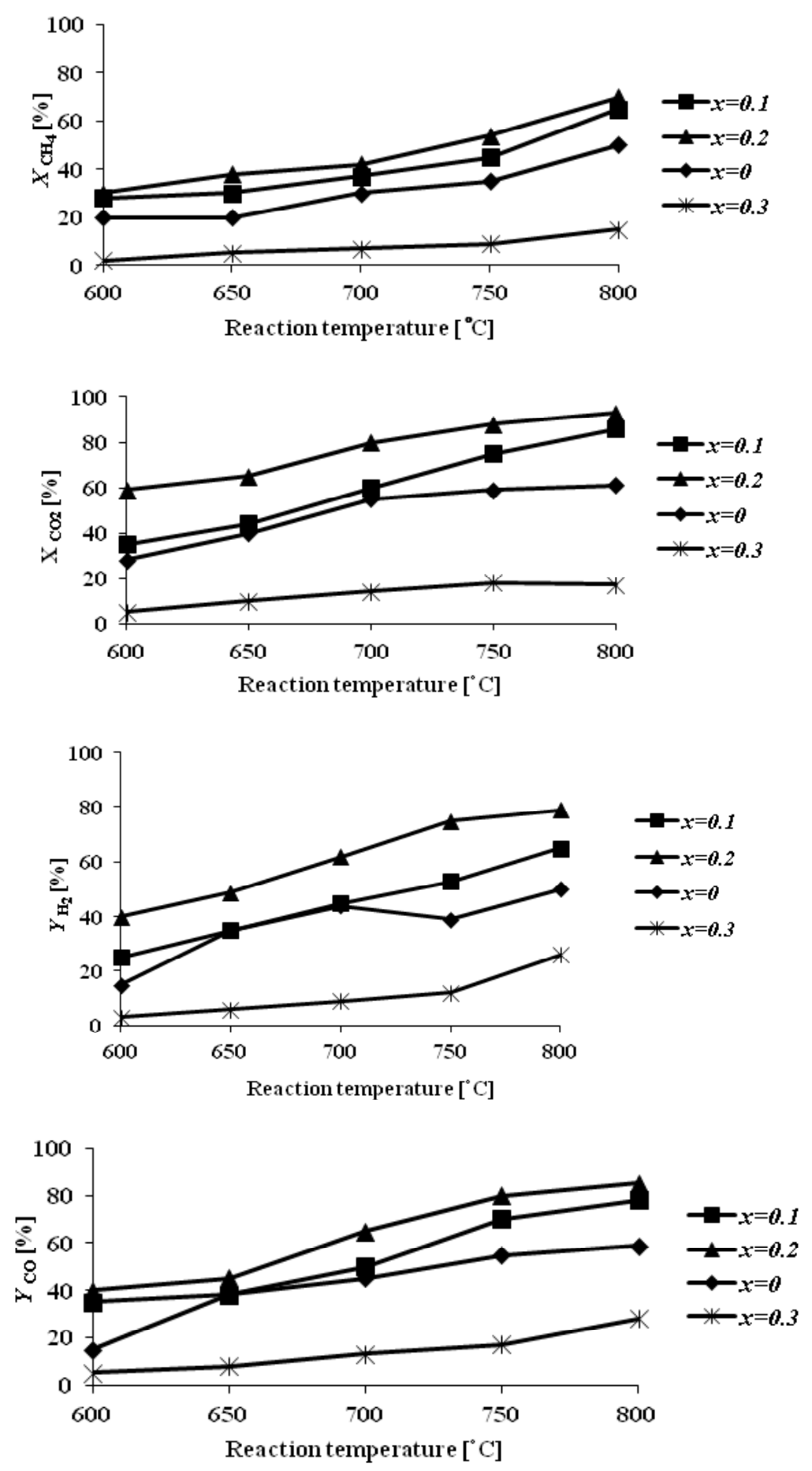

Fig. 5: $\mathrm{CH}_{4}$ and $\mathrm{CO}_{2}$ conversions, and $\mathrm{H}_{2}$ and $\mathrm{CO}$ yields as a function of the reaction temperature for reduced $\mathrm{La}_{1-x} \mathrm{Ce}_{x} \mathrm{Ni}_{0.4} \mathrm{Fe}_{0.6} \mathrm{O}_{3}$ samples in DRM process $\left(\mathrm{CH}_{4} / \mathrm{CO}_{2}=1 / 1\right.$ and WHSV $=15 \mathrm{l} /(\mathrm{h} . \mathrm{g})$ ) 

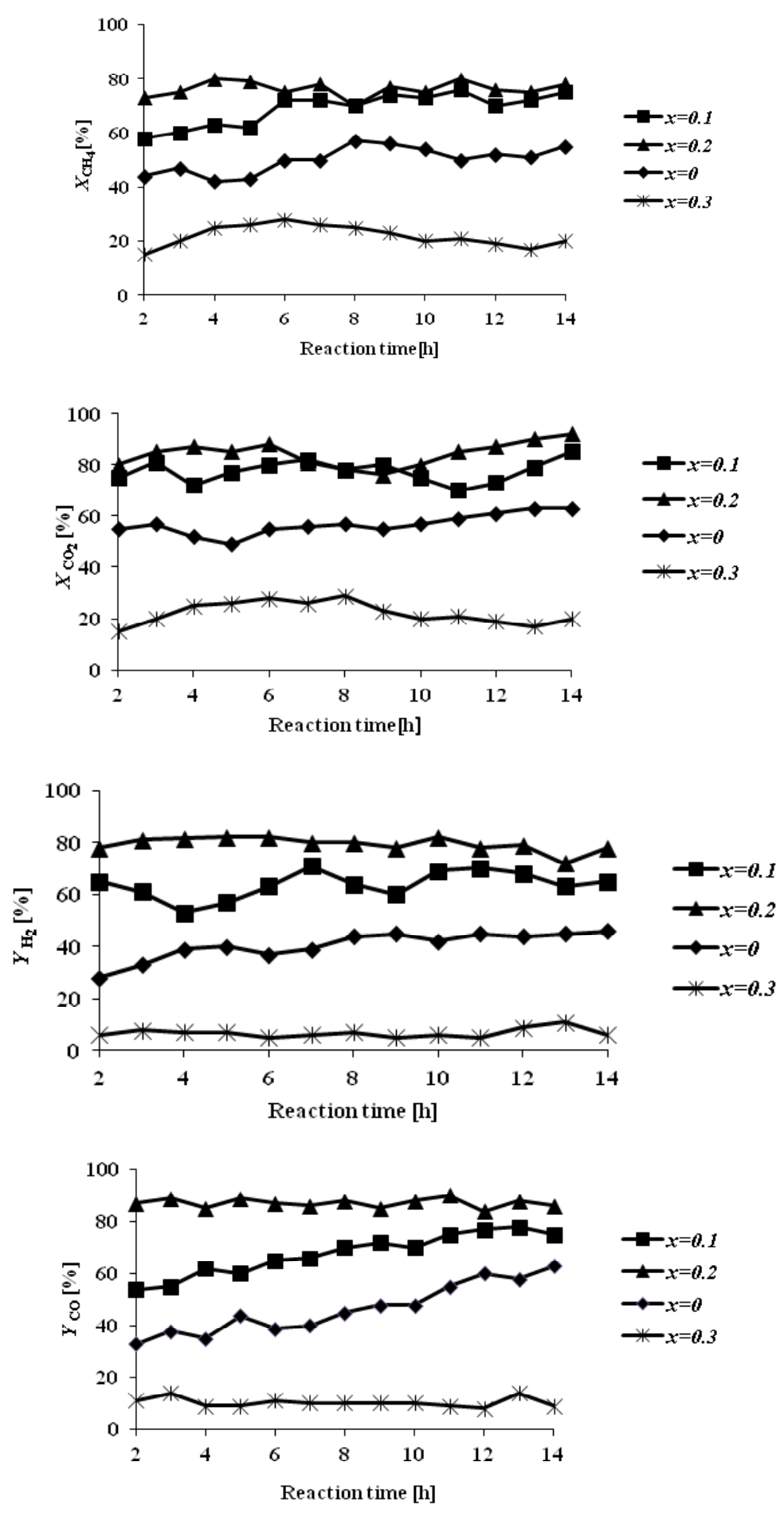

Fig. 6: $\mathrm{CH}_{4}$ and $\mathrm{CO}_{2}$ conversions, $\mathrm{H}_{2}$ and $\mathrm{CO}$ yields as a function of the reaction time for reduced $\mathrm{La}_{1-x} \mathrm{Ce}_{x} \mathrm{Ni}_{0.4} \mathrm{Fe}_{0.6} \mathrm{O}_{3}$ samples at $750^{\circ} \mathrm{C}$ in DRM process $\left(\mathrm{CH}_{4} / \mathrm{CO}_{2}=1 / 1 \mathrm{WHSV}=15 \mathrm{l} /(\mathrm{h} . \mathrm{g})\right)$ 


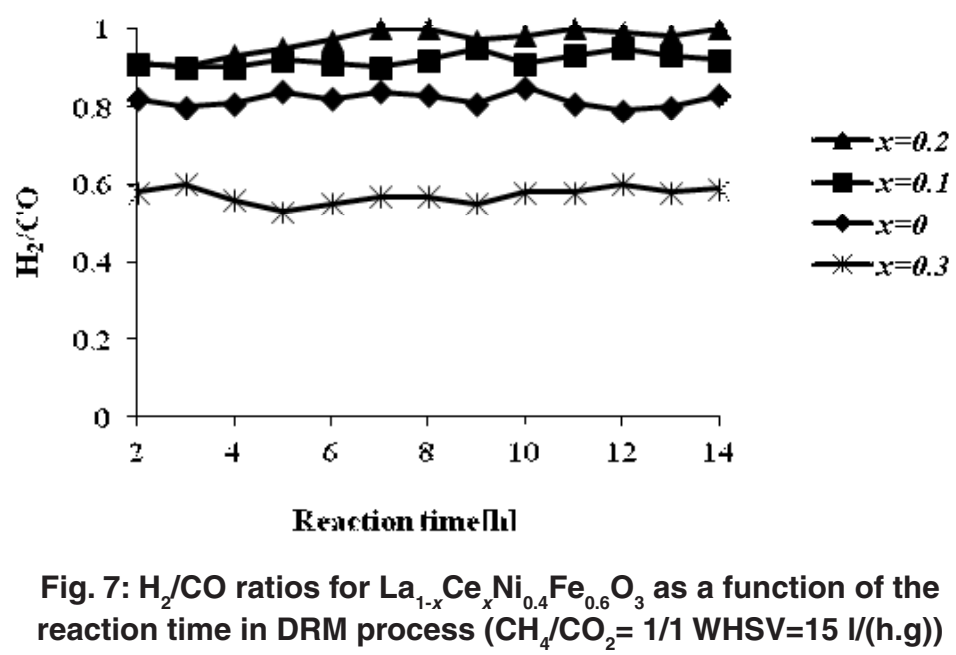

\& $\mathrm{CO}$ yields versus time at $750^{\circ} \mathrm{C}$ temperature for $\mathrm{La}_{1-x} \mathrm{Ce}_{x} \mathrm{Ni}_{0.4} \mathrm{Fe}_{0.6} \mathrm{O}_{3}$ samples. These diagrams show that the $\mathrm{CH}_{4} \& \mathrm{CO}_{2}$ conversions and $\mathrm{H}_{2}$ \& $\mathrm{CO}$ yields in the presence of the pure perovskite are higher than the catalysts containing more than one phase. Catalytic activity study of the prepared samples in fig. 7 also indicates that $\mathrm{H}_{2} / \mathrm{CO}$ ratio in the presence of $\mathrm{La}_{1-x} \mathrm{Ce}_{x} \mathrm{Ni}_{0.4} \mathrm{Fe}_{0.6} \mathrm{O}_{3}$ catalyst with doping level of $x=0.1$ and $x=0.2$ is $\sim 1$. It can be concluded that the reaction equation 1 is the main occurring reaction. $\mathrm{H}_{2} / \mathrm{CO}$ ratio is less than 1 in the presence of the catalyst with upper Ce doping level $(x>0.2)$ containing more than one phase. This ratio is also less than 1 for the sample without $\mathrm{Ce}\left(\mathrm{LaNi}_{0.4} \mathrm{Fe}_{0.6} \mathrm{O}_{3}\right)$. In general, in the presence of $\mathrm{La}_{1-x} \mathrm{Ce}_{x} \mathrm{Ni}_{0.4} \mathrm{Fe}_{0.6} \mathrm{O}_{3}$ samples, $\mathrm{CH}_{4}$ and $\mathrm{CO}_{2}$ conversions in DRM process depended on the content of $\mathrm{Ce}$. Thermal stability, high ionic conductivity, redox properties, and the oxygen transport properties of Ce played an important role in a good catalytic performance of these nanocatalysts ${ }^{3}$. High redox chemistry of cerium promotes the overall performance of the $\mathrm{Ni}$-based DRM catalysts ${ }^{14}$.

\section{CONCLUSIONS}

1. $\mathrm{La}_{1-x} \mathrm{Ce}_{x} \mathrm{Ni}_{0.4} \mathrm{Fe}_{0.6} \mathrm{O}_{3}(x=0.1,0.2)$ perovskite nanocatalysts were prepared by citrate sol-gel method and evaluated as catalyst precursors in the dry reforming of methane. Spherical particles with crystalline size in nanometer scale and well-defined structure were obtained.

2. TPR analysis revealed that partial substitution of $\mathrm{La}$ by $\mathrm{Ce}$ in $\mathrm{La}_{1-x} \mathrm{Ce}_{x} \mathrm{Ni}_{0.4} \mathrm{Fe}_{0.6} \mathrm{O}_{3}$ perovskite structure generated a change in the temperature of nickel reducibility and reduction process shifted to lower temperatures.

3. Ce-substitution rises $\mathrm{CH}_{4} \& \mathrm{CO}_{2}$ conversions and $\mathrm{H}_{2}$ \& $\mathrm{CO}$ yields by increasing both the BET surface area and the metal dispersion.

4. $\mathrm{CH}_{4} \& \mathrm{CO}_{2}$ conversions and $\mathrm{H}_{2}$ \& $\mathrm{CO}$ yields increased by increasing the temperature in the presence of the pure perovskite catalysts.

5. The most promising catalyst was the partially doped perovskite $\mathrm{La}_{0.8} \mathrm{Ce}_{0.2} \mathrm{Ni}_{0.4} \mathrm{Fe}_{0.6} \mathrm{O}_{3}$ that performed highest catalytic activity in comparison with other doping levels of $\mathrm{Ce}$.

6. The most important aim of this research is to investigate the appropriate $\mathrm{H}_{2} / \mathrm{CO}$ ratios in dry reforming of methane over $\mathrm{La}_{1-x} \mathrm{Ce}_{x} \mathrm{Ni}_{0.4} \mathrm{Fe}_{0.6} \mathrm{O}_{3}$ $(x=0.1,0.2)$ perovskite nanocatalysts to obtain more applicable chemicals of syn-gas in future as a novel research. Syn-gas can be applied in the Fischer-Tropsch synthesis industry to produce valuable chemicals 


\section{REFERENCES}

1. Valderrama, G.; Kiennemann, A.; Goldwasser, M.R. J. Power Sources. 2010, 195(7), 17651771.

2. Khalesi, A.; Arandiyan, H.R.; Parvari, M. Chin. J. Catal. 2008, 29 (10), 960-968.

3. Valderrmaa, G.; Goldwasser, MR.; Navarro, CU.; Tatibouët, JM.; Barrault, J.; Dupeyrat, CB.; Martinez, F. Catal Today. 2005, 107-108, 785-791.

4. Ferreira-Aparicio, P.; Guerrero-Ruiz, A.; Rodriguez-Ramos, I. Appl. Catal. Gen. 1998, 170 (1), 177-187.

5. Corthals, S.; Van Nederkassel, J.; Geboers, J.; De Winne, H.; Van Noyen, J.; Moens, B. Catal. Today. 2008, 138, 28-32.

6. Eltejaei, H.; Bozorgzadeh, HR.; Towfighi, J.; Omidkhah, MR.; Azari, M.; Zanganeh, R. Int. J. Hydrogen Energy, 2012, 37, 4107-18.

7. Pereniguez, R.; Gonzalez-Delacruz, VM.; Holgado, J P.; Caballero, A. Appl. Catal. B. 2010, 93(33), 346-353.

8. Lima, SM.; Assaf, JM.; Peòa, MA.; Fierro, JL. Appl. Catal. A. 2006, 311, 94-104.

9. Osojnik Èrnivec, IG.; Djinoviæ, P.; Erjavec, B.; Pintar, A. Chem. Eng. J. 2012, 207-208, 299-307.

10. Barroso-Quiroga, MM.; Castro-Luna, AE. Int. J. Hydrogen Energy, 2010, 35, 6052-6.

11. Rivas, JL.; Fierro, MR.; Goldwasser, PE.; Pérez-Zurita, MJ.; Griboval-Constant, A.; Leclercq, G. Appl. Catal. A 2008, 344, 1019.

12. Sierra Gallego, G.; Mondragón, F.; Barrault, J.; Tatibou, t, JM.; Batiot-Dupeyrat, C. Appl. Catal.
A: Gen. 2006, 311, 164-71.

13. Moradi, GR.; Rahmanzadeh, M. Catal. Commun. 2012, 26, 169-72.

14. Gallego German, S.; Marin Jaime, G.; BatiotDupeyrat, C.; Barrault, J.; Mondragon, F. Appl. Catal A: Gen. 2009, 369, 97-103.

15. Lima, SM.; Assaf, JM.; Pena, MA.; Fierro, JLG. Appl. Catal. A: Gen. 2006, 311, 94-104.

16. Choi, So.; Moon, SH. Catal. Today, 2009, 146, 148-53.

17. Lima, SM.; Silva, AM.; Costa, LOO.; Assaf, JM.; Mattos, LV.; Sarkari R. et al. 2012 , 121 122, 1-9.

18. Sutthiumporn, K.; Maneerung, T.; Kathiraser, Y.; Kawi, S. Int. J. Hydrogen Energy. 2012, 37, 11195-207.

19. Jahangiri, A.; Pahlavanzadeh, H.; Aghabozorg, HR. Int. J. Hydrogen Energy. 2012, 37, 99779984.

20. Jahangiri, A.; Aghabozorg, HR.; Pahlavanzadeh, $\mathrm{H}$. Int $J$ Hydrogen Energy. 2013, 38, 10407-10416.

21. Jahangiri, A.; Aghabozorg, HR.; Pahlavanzadeh, H.; Towfighi, J. Int. J. Chem. React. Eng. 2014, 12, 1-10.

22. Dejaidja, A.; Libs, S.; Kiennemann, A.; Barama, A. Catal. Today. 2006, 113(3), 194200.

23. Lima, SM.; Assaf, JM.; Pen a, MA.; Fierro, JLG. Appl. Catal. A: Gen. 2006, 311, 94104.

24. Pecchi, G.; Reyes, P.; Zamora, R.; Cadu' s, L.E.; Fierro, J.L.G. J. Solid State Chem. 2008, 181 (4), 905-912. 